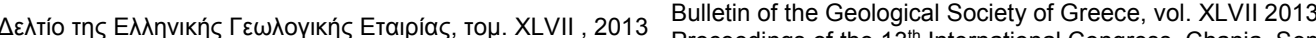
Proceedings of the $13^{\text {th }}$ International Congress, Chania Sept.

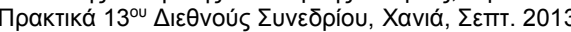
2013

\title{
"EXTRACTIVE INDUSTRIES TRANSPARENCY INITIATIVE-EITI" OUTLOOK ON THE EXPLOTATION OF ALBANIAN MINERAL RESOURCES
}

\author{
Shehu Ar. ${ }^{1}$ and Shehu Ag. ${ }^{2}$ \\ ${ }^{1}$ Aluizni-Drejtoria Qendrore, Rr. Skënder Kosturi, Tirana, Albania, arbishehu@gmail.com \\ ${ }^{2}$ Sekretariati për Transparencë në Industrinë Nxjerrëse- AlbEITI, Blloku "Vasil Shanto", Tirana, \\ Albania,shehu.agim@gmail.com
}

\begin{abstract}
Albania is focusing its efforts in the achievement of medium and long-term development objectives, particularly so its goals for European integration and the processes to this end. Local and foreign investments and projects in the Extractive industry are growing in the last years. Statistical data and references show an increased level of production and payments made to the state. Income from hydrocarbon sector constitutes the most important part of these payments, followed by the mining sector for the production of construction materials.

The level of production and income recorded in these sectors is increasing. Proof of this are the payments made to the government by the extractive industry year after year, thus showing consistency of the economic sector and a moderate impact on the state budget and other macroeconomic indicators.

Joining this initiative comes as a continuation of reforms undertaken for this purpose, in order to increase the transparency for all payments made to the Albanian State by the Extractive Industry. It follows the path of a broad program of economic, financial and institutional reform where transparency and proper management of natural resources have a particular importance. These two factors are essential for sustainable development. The new Mining Law and other by-laws, in addition to other changes required by legal improvements and economic development of the country, reflect the requirements of this initiative.

Key words: Natural Resources, EITI, Extractive Industries, Mining Economy, Mining Law.
\end{abstract}

\section{Introduction to EITI}

\subsection{What is EITI? Cumulative Data}

In many countries money generated from the production of oil, gas and minerals is associated with poverty, conflict and corruption. Thus, we are dealing with what often comes as a result of the lack of transparency and accountability with respect to the payments that companies make to the governments. Extractive Industries Transparency Initiative (EITI) aims to ensure the transparency and accountability that is lacking. Undertaken on a voluntary basis and supported by a coalition of companies, governments, investors and civil society organizations, this initiative combines the efforts aimed at improving the transparency of state budget practice, by starting a process that will

XLVII, No $3-2010$ 
provide opportunities to the citizens to urge their governments be accountable about the use of these incomes. (Mining Sector Reform, Restructuring and Future Prospects (June 2009).

Extractive Industries Transparency Initiative (EITI) supports the improvement of management in resource-rich countries through the verification and full publication of corporate payments and government income from oil, gas and mining.

Good governance is a precondition for converting large income from extractive industries into economic development and poverty reduction. When transparency and accountability are weak, extractive industries can promote poverty, corruption and conflict.

Extractive Industries Transparency Initiative (EITI) was launched by the British Prime Minister Tony Blair in Johannesburg in September 2002. The presentation was followed by the first EITI international conference, in Lancaster House, London, in June 2003, where participants from governments, extractive industries and civil society approved the following principles (www.eiti.org):

- Share a belief that the prudent use of natural resource wealth should be an important engine for sustainable economic growth that contributes to sustainable development and poverty reduction, but if not managed properly, can create negative economic and social impacts.

- Affirm that management of natural resource wealth for the benefit of a country's citizens is in the domain of sovereign governments to be exercised in the interests of their national development.

- Recognize that the benefits of resource extraction occur as revenue streams over many years and can be highly price dependent.

- Recognize that a public understanding of government revenues and expenditure over time could help public debate and inform choice of appropriate and realistic options for sustainable development.

- Underline the importance of transparency by governments and companies in the extractive industries and the need to enhance public financial management and accountability.

- Recognize that achievement of greater transparency must be set in the context of respect for contracts and laws.

- Recognize the enhanced environment for domestic and foreign direct investment that financial transparency may bring.

- Believe in the principle and practice of accountability by government to all citizens for the stewardship of revenue streams and public expenditure.

- Are committed to encouraging high standards of transparency and accountability in public life, government operations and in business,

- Believe that a broadly consistent and workable approach to the disclosure of payments and revenues is required, which is simple to undertake and to use.

- Believe that payments' disclosure in a given country should involve all extractive industry companies operating in that country.

- In seeking solutions, we believe that all stakeholders have important and relevant contributions to make - including governments and their agencies, extractive industry companies, service companies, multilateral organizations, financial organizations, investors, and nongovernmental organizations.

Extractive Industries Transparency Initiative is now a global initiative supported by an International Secretariat based in Oslo, Norway, and the Council, which consists of representatives of countries, companies, civil society groups, investors and donors, who are committed to the implementation of EITI.

XLVII, No 3 - 2011 


\subsection{How does EITI Work?}

The International Secretariat of the Extractive Industries Transparency Initiative works closely with the World Bank and the IMF and is responsible for daily activities related to the EITI, communication with stakeholders and organization of the Council's annual conferences by establishing important relationships through a global scale outreach and publicity program. Local EITI secretariats have been established in each implementing country. In addition to the implementing governments, EITI relies on the support from donors, many large oil companies in the world mining industry, as well as investors in those companies. They are also supported by civil society groups, many of which operate under the global Coalition "Publish what you pay".

\subsection{What are the Advantages of EITI Implementation?}

The entities that benefit the most from EITI are the governments and the citizens of resource-rich countries. Knowing how much companies pay and how much governments get is an essential first step in asking information from the decision-makers regarding the use of income. Resource-rich countries, which implement EITI, can benefit from the improved investment climate by to the investors and international financial institutions a clear signal that the government is committed to greater transparency and accountability. By supporting EITI in countries where they operate, companies and investors can contribute to mitigate investment risk. Civil society can benefit from the increased amount of information in the public sector for the incomes that governments manage on behalf of the citizens.

In brief, "implementing the EITI in the framework of the program for improving governance will serve to ensure that incomes from oil, gas and mining activities promote sustainable development and the poverty reduction."

Joining this initiative improves foreign business climate in the mining sector, increases investments in this sector, and creates the conditions for a broader participation of local business in mining activities. It provides new opportunities for finding donors for various funding, improvements to the legislation or other projects related to mining activities mainly related to the establishment of relations between government bodies and the public, etc.

\subsection{EITI Criteria}

During the EITI International Conference, held in London in March 2005, participants agreed on the EITI criteria. The Conference served to announce what countries should do to successfully implement EITI. Implementation of EITI must be consistent with the following Criteria (www.eiti.org):

- Regular publication of all the oil, gas and mining companies payments made by the companies to the government ("payments") and all revenues received by governments from oil, gas and mining companies ("revenues") to a wide audience in a publicly accessible, comprehensive manner.

- Where such audits do not already exist, payments and revenues are the subject of a credible, independent audit, applying international auditing standards.

- Payments and revenues are reconciled by a credible, independent administrator, applying international auditing standards and by the publication of the administrator's opinion regarding the matter.

- This approach is extended to all companies including state-owned enterprises.

- Civil society is actively engaged as a participant in the design, monitoring and evaluation of this process and contributes towards public debate. 
- A public, financially sustainable work plan for all the above mentioned is developed by the host government, with assistance of the international financial institutions where required, including measurable targets, a timetable for implementation, and an assessment of potential capacity constraints.

\subsection{How is EITI Implementation Financed?}

Extractive Industries Transparency Initiative is supported by the legislation in force in the implementing countries. It is financed from implementing countries resources and partly through a Multi Donor Trust Fund (MDTF) managed from the World Bank. Furthermore, other donors provide some special funds for EITI implementation as per each country.

\section{Community Profit Distribution Mechanism}

\subsection{Sustainable Communities}

Sustainable communities are the outcome of good policies and laws that are planned and implemented at local level from the responsible institutions/organizations, with the active participation of community members. Some of the key instruments to ensure that local communities benefit from extractive industries are:

- community consultation framework, to assess and determine the roles and responsibilities of government(s), company(ies), non-governmental organizations, donors and the affected local communities on the measures to address the environmental and social impacts;

- community development plan, which is coordinated by the Government, both at central and local level, in consultation with stakeholders, including the active participation of communities, aiming the mainstreaming of mining operations and planning the closure of mines in broader economic plans at regional level.

The ultimate goal should be the transformation of the community from a mere beneficiary to a reliable partner.

\subsection{Local Communities}

Local communities affected by mining activities may be offered a wide range of benefits. These include: the provision of infrastructure in rural areas, the establishment of small and medium enterprises, building human resources through trainings that support companies, thus providing professional skills either to work directly in the mines, or in supporting secondary industries.

In principle, the full package of benefits for the community should include:

\section{- Employment and income related benefits}

\section{- Benefits aimed at building local human resources and institutional capacities}

- Community benefits resulting from the establishment of infrastructure - providing access to: (i) education (schools); (ii) markets, where local communities sell their products (roads); (iii) health care (medical facilities); and (iv) potable water etc., which, ideally, should be supported by the investor and the government and managed by the community. The distribution of benefits will be effective if the accumulation of human and social capital is promoted, by improving health care and education standards for the local population, as well as its collective ability to organize, prioritize, represent and negotiate effectively its interests towards third parties, such as the Government.

\section{3. Trust Funds}

These funds are effective mechanisms to support the accumulation of human and social capital that are either: 
- Set up to finance local development initiatives and be managed by the community, according to its needs;

- Or set up to provide funds for future generations.

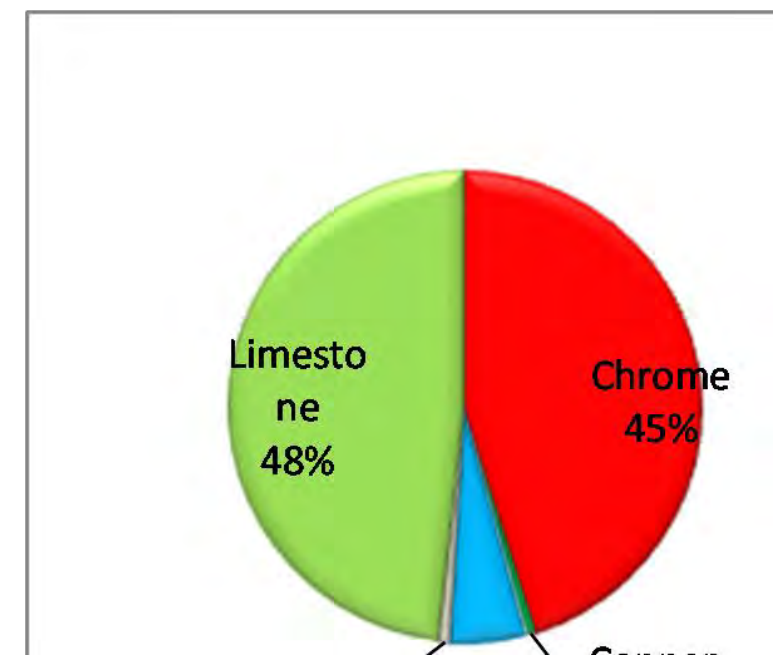

Chart 1 - Albanian Companies Operating in the Mining Sector.

\subsection{Measures for the Distribution of Benefits from the Mining Sector}

\subsubsection{Mineral Property Royalties}

The mining Law clearly stipulates that $25 \%$ of the mineral property royalties shall be paid to the local communities in the areas where mines for which exploitation permits are issued are located, while the rest shall be paid to the central government.

It would have been fairer if mineral property royalties were paid directly to the local government from the beneficiary company, and then reconciled with the central government payments for coordination and audit.

\subsubsection{Model of the Community Development Forum}

The forum has two main functions. The first function is to serve as a place for the exchange of information on the project between the user and the central and local government and landowners regarding the nature, scope and impact of the project. The second function is to determine how the various stakeholders will allocate the benefits of the project, which will then be reflected in the number of agreements for the project, or MoUs.

These agreements define the roles and responsibilities of all involved parties (government, mining companies and community), and include services and benefits that will be provided to the affected project area. To be mentioned among them is the provision of community infrastructure and sharing of financial benefits of the project. In exchange for the benefits, the community and landowners are committed not to interrupt the implementation of the project, and to cooperate with the government and the company. These agreements bind the parties to an ongoing process of consultations, where issues related to the development can be discussed and resolved during the process. This initial consultation process and drafting of various agreements should be finalized before the endorsement of the Development/Concession Agreement between the government and the mining companies. 
This broad participation approach, which emphasizes cooperation and mutual obligations, has a number of key advantages.

- First, it provides a flexible model that can adapt to diverse issues and needs of different communities.

- Second, it is a comprehensive approach, and all relevant stakeholders are part of the management and decision-making based on communication, consultation and negotiation.

- Third, the approach has essentially a democratic and participatory character. People in the mining area play an active role in decision-making.

- Finally, the Development Forum should have strong legal grounds and it represents applicable contracts. Therefore, it constitutes reliable and legally binding commitments, which create the trus ty.

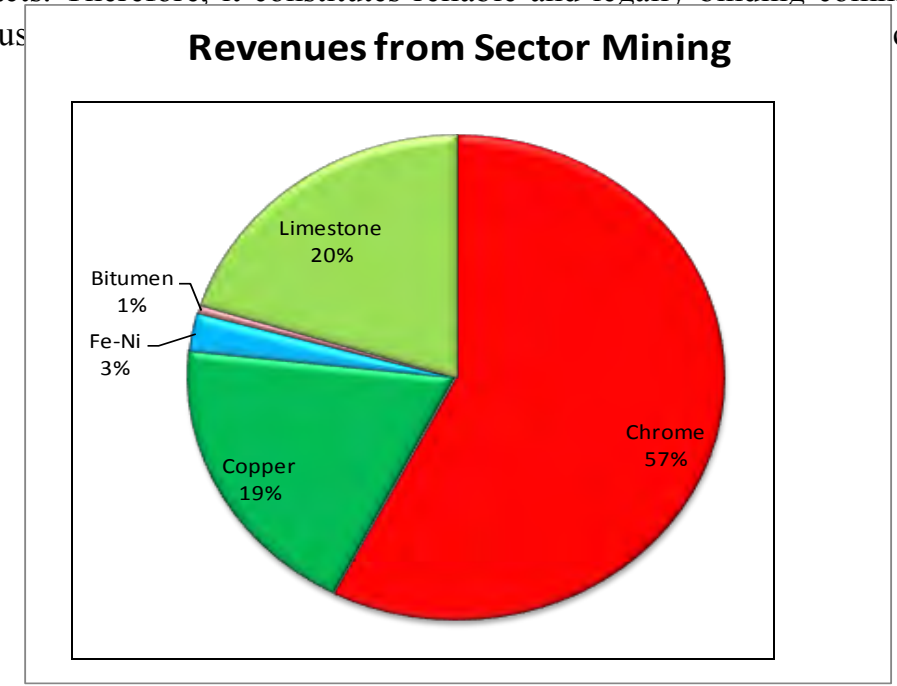
conomic activi-

Chart 2 - Revenues from Mining Sector.

\section{Interpretations and Conclusions}

\subsection{What do EITI Reported Data Show?}

With income amounting to USD 3,950 per capita and a GDP of USD 12.168 million, Albania's extractive industry is based mainly on the hydrocarbon and mining sector.

The first EITI report on Albania was published in May 2011 with 2009 data. Data and statistical references show a payment level of USD 33.962 million made by these sectors of extractive industry, representing a moderate contribution to state income balance-sheet by about $1 \%$ and in the country's GDP by $0.3 \%$. The mining sector accounts for $6 \%$ of payments made to the state in the extractive industry, as compared to the hydrocarbon sector, accounting for $94 \%$.

According to the EITI report, incomes in 2009 amount to USD 10.6/capita only from the extractive industry. The data were evaluated and reviewed by the independent administrator, a foreign company "Fair Links" Srl, France, for 2009; the company is compiling the report for 2010, as part of the assessment work that is being done for Albania's participation in EITI's international structure.

Based on the respective reports and data it results that the majority of liabilities and payments made by manufacturing companies in favor of the state are:

- Signature bonuses

- Mineral royalties

- Corporate profit tax 
- Surface fees

- Other important payments made to the state

The analysis for companies and the criteria for their inclusion in EITI report 2009 are mainly based on:

- Productivity (production) accounting for a considerable share in their activity;

- Revenue to state;

- Surface areas.

Table 1 - EITI declarations on the oil sector.

\begin{tabular}{|l|l|c|c|c|c|}
\hline Ref & \multicolumn{1}{|c|}{ In K USD } & $\begin{array}{c}\text { Private Oil } \\
\text { Companies (1) }\end{array}$ & $\begin{array}{c}\text { Alb Petrol } \\
\text { (2) }\end{array}$ & State (3) & (1) -(2)-(3) \\
\hline A & Signature bonuses (exploration phase) & 160 & - & 160 & 0 \\
\hline B & Royalties & 8828 & - & 8175 & 653 \\
\hline C & Corporate profit tax (Private Oil Companies) & 0 & - & 0 & 0 \\
\hline D & Signature bonuses (production phase) & 0 & 50 & - & $(50)$ \\
\hline E & Share of Production allocated to Alb-Petrol & 22915 & 22915 & - & 0 \\
\hline F & Corporate profit tax (Alb Petrol) & - & 0 & 0 & 0 \\
\hline G & Dividends (Alb Petrol) & - & 0 & 0 & 0 \\
\hline & Total & $\mathbf{3 1 9 0 3}$ & $\mathbf{2 2 9 6 5}$ & $\mathbf{8 3 3 5}$ & \\
\hline
\end{tabular}

To this end, companies that occupy a significant share in the production and income generated in the mining production and hydrocarbons were assessed, i.e. those providing higher payments to the state.

Therefore, the sectors and companies that have exploitation permits, while assessing their activity in 2009 and 2010 were analyzed.

In the EITI report on the reconciliation of payments from the extractive industry sector in Albania in 2009, the independent administrator "Fair Links" Srl, France declared that, for the oil sector, payments of companies to the state amount to USD 31.903 million, of which $27.7 \%$ or USD 8.828 million in the form of mineral royalties, whereas in the mining sector payments amount to USD 2.059 million, of which $48.6 \%$ or USD 1 million in the form of mineral royalties. The analysis shows that the relevant amounts were reconciled based on EITI criteria and that they are evidence of state budget support and the opportunity for funding of projects in extractive industries.

In the 2010 report it was proposed to increase the level and number of indicators that will be analyzed as compared to the 2009 report, to include:

- a larger number of companies, for example from 48 in 2009 to 118 in 2010 (109 from mines and 9 from hydrocarbons),

- companies that produce construction materials,

- companies that produce bitumen and tar sands,

- all oil companies in Albania.

The proposals related to the limit of income generated and consequently the payments to be deposited to the state from the companies included in the 2010 EITI report are as follows:

- increase the number from about $60 \%$ to minimum $70 \%$ for the mining industry companies

- reach a percentage of $100 \%$ for companies in the hydrocarbons sector. 
Table 2 - EITI declarations on the mining sector.

\begin{tabular}{|l|c|c|c|}
\hline \multicolumn{1}{|c|}{ In M USD } & Companies (1) & State (2) & (1) \\
\hline Signature bonuses & 0.2 & 0.1 & 0.1 \\
\hline Surface fees & 12.2 & 12.1 & 0.1 \\
\hline Royalties & 93.1 & 92.5 & 0.6 \\
\hline Corporate profit tax & 86.2 & 81.4 & 4.8 \\
\hline \multicolumn{1}{|c|}{ TOTAL } & $\mathbf{1 9 1 . 7}$ & $\mathbf{1 8 6 . 1}$ & $\mathbf{5 . 6}$ \\
\hline
\end{tabular}

Improvements to the extractive industry legislation, regulations and updated guidelines for highlighting the development and growth of investments, income, payments to the state, growth and structural improvements to the local budget of areas where extractive industries operate- are very favorable factors for the positive assessment done for Albania's participation in the EITI.

The activity and level of implementation of granted permits for use, along with the analysis of the results achieved on the level of implementation of the exploration permits, which were granted to private local and foreign companies, have to be analyzed, reconciled and described fully and clearly in the analytical statements of EITI reconciliation report in Albania based on the information, publication and broad public discussion, by referring to 2009, 2010 onwards.

The experience gained and the results obtained from the implementation of the first 2009 EITI Report, with 2009 being the baseline year (www.albeiti.org), the recommendations given by the EITI International Secretariat regarding the assessment of the work and achievements of Albania so far, are encouraging. The assessment conducted at the meeting of the Board of the EITI International Secretariat in October 2011 states that "The Board congratulates the government, the companies and civil society in Albania for the meaningful progress in implementing EITI". This requires the work and follow up process to be in accordance with the principles and criteria set out in the EITI rules.

In this regard, the main goal of this work is to achieve full compliance of the tasks, criteria and support the communities in the areas of extractive industry in order to implement EITI as part of a program for improving governance in order to serve and guarantee that the income from oil, gas and mining activities in the country promote sustainable development and poverty reduction.

\subsection{EITI Implementation Results}

The implementation of programs for Albania's membership in the EITI, according to the principles, criteria and rules of EITI is an on-going process. The legislation on the mining sector has improved, reflecting the requirements and the economic development of the country. The application of international auditing regulations in the extractive industry companies in the country has improved as well.

EITI process is public and widely discussed, by having collaboration between government, stakeholders and civil society in order to promote sustainable development and poverty reduction.

EITI reports for 2009 and 2010 and the guarantee for the submission of reports for the coming years are a positive example for Albania, wishing to become a member with full rights in the EITI.

Central and local governments collaborate in programs and projects applicable to the extractive industry areas but this must be accompanied by an increase in the level of consultation with stakeholders and communities in these areas.

XLVII, No $3-2017$ 
Community consultation framework is important in order to evaluate and assign roles and responsibilities of government, civil society, non-governmental organizations, donors, and local communities on measures to address the environmental and social impacts.

The establishment and operation of development forums in the communities of extractive industry areas is proposed. The final objective should to be turning the community from a mere beneficiary to a reliable partner (EITI Business Guide, How companies can support implementation).

\section{Acknowledgements}

We would like to express our gratitude to all those who gave us the possibility to complete this article. We want to thank METE, the National Agency for Natural Resources of Albania (AKBN), AlbEITI Secretariat and the World Bank Mission in Albania.

\section{References}

Albania-National Strategy for Development and Integration 2007 to 2013 - Government of Albania, Council of Ministers (March 2008). Available at web site: http://mie.gov.al/skedaret/1226905647-NSDI.pdf

Albania-Mining Sector Reform, Restructuring and Future Prospects (June 2009) - World Bank. Available at web site: http://www-wds.worldbank.org/external/default/WDSContentServer/ WDSP/IB/2009/07/21/000333037_20090721002237/Rendered/PDF/475390ESW0P1101C ODisclosed071171091.pdf

Albania-Business and Investment Development Strategy 2007 to 2013 - METE (February 2007). Available at web site: http://www.mete.gov.al/doc/20071218084802 business and investment development strategy.pdf

Albania-World Bank, Report Nr. 47539-AL " Albanian mining sector reform, restructuring and future prospects", June 2009.

AlbEITI Secretariat, Work Plan for 2011-2013, Tirana 2011 Available at web site: www.albeiti.org

EITI Board Meeting, Board Paper Nr. 18-5-A, Validation: Albania, 25-26 October 2011, Jakarta

EITI Secretariat, Extracting Data - Overview of the EITI Reports published 2005-2011,Oslo, 2011. Available at web site: www.eiti.org

EITI Secretariat, EITI Rules including validation guide, 2011 Edition, Oslo, April 2011 Available at web site: www.eiti.org

EITI Secretariat, EITI Business Guide, How companies can support implementation, Oslo, 2008

Fair Links srl, France, Republic of Albania- EITI report for the year 2009, April 2011

Kalaja D. Communication Strategy and Action Plan for AlbEITI, June 2011, Tirana

Legislation in force, Law Nr.10304, dated 15.07.2010 "On the mining sector in the Republic of Albania ", other legal acts in force.

Mati S. - Mining policy for a sustainable development of mining activities- Workshop, Tirana 2010.

METE, JICA, Progress Report " The study for the master plan for promoting the mining industry of Albania", Tirana, November 2009. 